\title{
Essays
}

\section{How Not to Succeed in Law School}

\author{
James D. Gordon III $\dagger$
}

\section{SHOULD YOU GO TO LAW SCHOOL?}

Would you like to help the less fortunate?

Would you like to see liberty and justice for all?

Do you want to vindicate the rights of the oppressed?

If so, you should join the Peace Corps. The last thing you should do is attend law school.

People basically hate lawyers, and with good reason. That's why you'll rarely escape from a dinner party without hearing at least one lawyer joke. Indeed, literature reveals that people have always hated lawyers. Samuel Coleridge wrote in The Devil's Thoughts:

He saw a Lawyer killing a Viper

On a dunghill hard by his own stable;

† Professor of Law, Brigham Young University Law School. B.A. 1977, Brigham Young University; J.D. 1980, Boalt Hall School of Law, University of California, Berkeley. Just for the record (in case I am ever nominated for a judicial appointment), I don't believe a word of this Essay. And if I do, I'm only being tentative. And if I'm not, I promise to let my colleagues dissuade me from my position shortly before the Senate confirmation hearings begin. After all, I watched the Bork hearings, too. I extend apologies and thanks to Dave Barry, Eliot A. Butler, Linda Bytof, Johnny Carson, Steven Chidester, Jesse H. Choper, Michael Cohen, Paul Duke, Vaughn J. Featherstone, J. Clifton Fleming, Jr., Frederick Mark Gedicks, Bruce C. Hafen, Carl S. Hawkins, Gregory Husisian, Brian C. Johnson, Edward L. Kimball, Jay Leno, Hans A. Linde, Thurgood Marshall, H. Peter Mueller, Richard Pryor, DeWitt Scott, Marjorie Maguire Shultz, Steven D. Smith, John S. Tanner, Toby Alaska Threet, Mark Twain, Mark O. Van Wagoner, Jan Vetter, J. Clifford Wallace, Henry Weihofen, D. Robert White, Kevin J. Worthen, Timothy R. Zinnecker, and others. 
And the Devil smiled, for it put him in mind Of Cain and his brother, Abel. ${ }^{1}$

Even other species detest lawyers. Carl Sandburg wrote:

Why is there always a secret singing

When a lawyer cashes in?

Why does a hearse horse snicker

Hauling a lawyer away? ${ }^{2}$

It is true that some lawyers are dishonest, arrogant, greedy, venal, amoral, ruthless buckets of toxic slime. On the other hand, it is unfair to judge the entire profession by a few hundred thousand bad apples. In fact, there are many perfectly legitimate reasons for going to law school. For example, ask yourself the following questions:

Do I want to go to medical school but can't stand the sight of blood?

Are my inlaws pestering me to death to do something meaningful (i.e., lucrative) with my life? Have I considered circulating petitions to ban inlaws, but realized that it would only spawn stupid bumper stickers saying, "WHEN INLAWS ARE OUTLAWED, ONLY OUTLAWS WILL HAVE INLAWS"?

Did I major in English and have absolutely nowhere else to turn?

If these questions ring a bell, you might feel that law school is for you. Lie down for a while until the feeling goes away. If it doesn't go away, prepare yourself for the consequences. For example, your grandparents will immediately scrape off their bumper sticker that says, "ASK ME ABOUT MY GRANDCHILDREN." You see, they grew up in a time when a person's word was his bond, when a handshake was enough, when disputes were worked out amicably and quickly among people of good will. Fortunately, you don't live in such primitive times! Today, you can make a handsome income exploiting other people's personal tragedies and society's declining sense of community. And just in time, too-right when you are graduating from college. Talk about lucky!

\section{TAKING THE LSAT}

Before you can go to law school, you have to take an exam called the LSAT. Nobody knows whether the "A" in LSAT stands for "Admissions," "Aptitude," or "Arbitrary." The LSAT basically measures how well you can use a number 2 pencil to fill in the little circles on the computer sheet. Be sure to fill in the circles completely and carefully. Do not make any stray marks on

1. S. COLERIDGE, The Devil's Thoughts, in THE COMPLETE PoEtical WORKS OF SAMUEL TAYLOR COLERIDGE 320 (1912). (1950).

2. C. SANDBURG, The Lawyers Know Too Much, in THE COMPLETE Poems of CARL SANDBURG 189 
the paper. This will lower your score. The instructions at the top of the exam carefully explain that these are the grading criteria, but hardly anyone ever pays any attention to them.

The old LSAT scores went up to 800 , but a few years ago the LSAT people (whoever they are) changed the exam so that now the highest possible score is 48 . This looks pretty suspicious, if you ask me. I mean, why 48 ? Why not a nice round number, like 100 ? The secret truth is that a group of law professors who scored 48 on the old exam lobbied the LSAT people to make 48 the highest score.

The old LSAT had-I am not making this up-a math section. After conducting an exhaustive nationwide study, however, the LSAT people finally realized that no one had asked a lawyer to solve a quadratic equation or find the cosine of an angle for, probably, several centuries, and so they eventually deleted it. This action was taken against their better judgment (using the term loosely). After all, the math section provided a handy way to discriminate among people of equal intelligence.

Frankly, the current LSAT isn't much better. It asks questions like, "Compare Madam Defarge in A Tale of Two Cities with Huckleberry Finn in Huckleberry Finn." This makes no sense at all, since lawyers rarely address this question.

Another typical question on the current LSAT goes like this:

Assume you have a fox, a goose, and a bag of corn. You need to row them all across the river, but the boat will carry only you and one other thing at a time. If you leave the fox and the goose alone, the fox will eat the goose. If you leave the goose and the corn alone, the goose will eat the corn. How do you get them across?

The answer is so simple a child could get it: you beat the goose silly with an oar, and then take the fox across before he flees for his life. This question is so stupid I don't even know why they include it.

It never seems to have occurred to the LSAT people that their test might deign to include a few questions that actually relate to a lawyer's work. For example:

(1) Abe is a lawyer who wins a personal injury lawsuit for Bet-

ty, a quadriplegic. Abe should take a contingent fee of:

a. 308

b. $50 \%$

c. $100 \%$

d. (The correct answer) 100\%, plus a bonus for taking a public service case. 
Or:

(2) The judge receives a bribe of $\$ 5,000$ from the plaintiff's

lawyer. He then receives a bribe of $\$ 10,000$ from the

defendant's lawyer. The judge should:

a. Notify the state bar association

b. Notify the police

c. Notify the FBI

d. (The correct answer) Return $\$ 5,000$ to the defendant and try the case on the merits.

The LSAT people say that LSAT preparation courses do not help, since the LSAT tests knowledge and skills that cannot be improved by last minute cramming. Regardless of what the LSAT people say, however, you will notice that there are several suspiciously solvent LSAT prep course companies who are happy to take your money. Of course, you can always choose to "go bare" and take the LSAT without any prep course at all. People who have done this in the past are called "nonlawyers."

You take the LSAT in a stifling room crammed with five hundred sweating people. It is immediately apparent that none of them has ever watched a deodorant commercial in his or her entire life. Through a strange quirk of fate, you have to sit right next to some moron who chomps loudly on Corn Nuts throughout the whole exam while wearing those artillery-range ear protectors that make it impossible for him to notice anything less than 7.5 on the Richter scale. They also make it impossible for you to tell him what an inconsiderate imbecile he is. Notice your feeling of panic and nausea as you take the LSAT. Get used to it.

After you take the LSAT, they send you your score and a statement explaining which "percentile" you are in. The "percentile" is the inverse percentage chance you have of spending your life doing something honest.

\section{Choosing a Law SCHOOL}

There are lots of fine law schools to choose from. For instance:

Harvard. Harvard is number one, as you can learn by asking anyone who went to Harvard. Or even if you don't ask. The only disadvantage of going to Harvard is that the graduation robes are the same color as Balls O' Fire Salmon Eggs.

Yale. Forget about Yale. It's so selective that no one ever goes there. If you find this statement doubtful, ask yourself this simple question: Do you personally know anyone who is going there now? Of course not. Oh, sure, there are lots of people who say that they went there in the past, now that it can't be verified. Don't you be fooled. 
Michigan. This is a good school, except the official school drink is Prestone. As each winter comes to an end, someone will have to remind you not to stare at that big yellow ball in the sky.

Chicago. Learn how many Chicago law professors it takes to screw in a light bulb. (Answer: None. The market will take care of it itself.)

Boalt Hall (Berserkeley). Boalt is built on a hill overlooking one of the most spectacular views on earth: the San Francisco Bay and the Golden Gate Bridge. Therefore, they naturally designed the building so that all its huge picture windows face directly into the fraternity houses across the street. You can't catch a glimpse of the Bay, but you do have a terrific view of fraternity blobs sitting around in their gym shorts, drinking beer, belching, and listening to the music of Twisted Sister at 300 decibels. Oh well.

Columbia. On the front of the law school building at Columbia, you will notice a huge sculpture of a man who has put a noose around the neck of a horse and is throttling it to death. You will not be able to understand the true significance of this sculpture until several days into your first year at Columbia.

Northwestern. Northwestern deliberately charges the highest tuition, on the theory - called the "Ray-Ban Theory"- that people will note the price tag and conclude that it must be the best school. Its goal is that eventually people will refer to Harvard as "the Northwestern of the Northeast."

Other Top Ten Law Schools. There are about twenty-five schools in this category. Consult this week's AP and UPI polls.

The "Middle Group." The Middle Group includes all other accredited law schools. These schools actually teach the law.

About Two Thousand Unaccredited California Law Schools. For example: Frank and Morty's School of Law and Cosmetology of the Lower Level of the Seven Hills Shopping Mall. Don't let the classy name fool you. There are basically two requirements for admission to this institution:

1. A pulse, and

2. $\$ 12,000$.

The first requirement can be waived.

Be sure to avoid law schools with "Jr." in the name, such as "Leland Stanford, Jr. Law School." These are actually junior law schools.

People often ask whether it's important that they attend a law school in the state where they intend to practice. The answer, of course, is NO. A good law 
school's curriculum is not tied to the law of any particular state. This is also true of the "elite" law schools, except that their curriculum is not tied to the law of any particular planet. You should attend one of those schools if you intend to practice law somewhere in the Andromeda Galaxy.

\section{APPLYING TO LAW SCHOOL}

You will need to submit applications to several law schools, which will cost you fifty bucks a pop. Law schools have you fill out lengthy application forms which require you not only to provide your GPA and your LSAT score, but also to describe your unique abilities and experiences, and the ways in which you might add to the rich fabric of the law school class. It takes you about eighty hours to fill out each of these forms. It takes you even more time to write and polish and repolish the "personal statement." Check over your personal statement carefully to make certain that you have used the two key words every law school looks for: "endeavor" and "cognitive." If all else fails, slip in a sentence such as: "I have always endeavored to be cognitive in all my cognitive endeavors."

When the law school receives your application, it banks your check, adds up your GPA and your LSAT, and throws the rest of the application away. No sane admissions officer is going to wade through 6,000 personal statements. And no law school in its right mind would take the risk of letting you know that your scores are all that matters. If you knew that, you might not apply in the first place. Multiply fifty bucks times 6,000 applications, and you can begin to see their point.

Anyway, after submitting the applications, you will receive several letters saying, "CONGRATULATIONS!!! You are on the 'hold' list for getting on the 'preliminary waiting list' to be considered for admission." They want to make sure that they can fill their class and get the tuition money they need, so they won't reject you until after they see how many students show up on the first day of class. I mean, what does it hurt them if you give up your other career plans and lifelong ambitions, right? Do you want to go to law school or not? OK, then stop whining.

Then, finally, you get accepted.

\section{THE FIRST YEAR}

Remember those horror movies in which somebody wearing a hockey mask terrorizes people at a summer camp and slowly and carefully slashes them all into bloody little pieces? That's what the first year of law school is like. Except it's worse, because the professors don't wear hockey masks, and you have to look directly at their faces. 
At first, it's not so bad. You get to read a semi-interesting medieval case in which somebody says, "Forsooth, were it not that Birnam Wood had come to Dunsinane, I would unseam thee from the nave to the chaps." But the honeymoon ends when you have to go to your first class. The professor has a black belt in an ancient martial art called "the Socratic method." 3 After the professor completely dismantles a student for sheer sport and humiliates several dozen others, he then points out forty-seven different things in the two-paragraph case that you failed to see and still don't understand. You leave class hoping that maybe there is still a job opening at your brother-in-law's toothpick recycling factory. You are beginning to learn why law school has been compared to a besieged city: everybody outside wants in, and everybody inside wants out.

Many students write "case briefs," or one-page summaries of the cases, before class, in case the professor calls on them. This is a good strategy if you have the slightest aversion to utter humiliation. The brain is a truly wonderful thing: it works from the instant you awake until you go to sleep, and it doesn't stop until the moment you get called on in class, when it suffers a complete and immediate core meltdown. Your professor and 150 other students are waiting patiently for you to state the facts of a given case, and the only sound in the room is a low gurgling rattle coming from the back of your throat.

The key to the Socratic method is that the professor never reveals what the answer is. He keeps insisting that THERE IS NO ANSWER. Consistent with this view, he spends the whole class period asking questions that no one even begins to understand. To get the answers, you have to buy commercial outlines, which cost $\$ 16.95$ apiece and are published by the same people who publish Cliffs Notes and Key Comics. The commercial outlines are written by the professors and provide them with a handsome income on the side. To insure that you will buy them, the professors tell you that, whatever you do, DO NOT buy any commercial outlines, because they will make it TOO EASY for you, and you will not develop the analytical skills and hard work ethic that law school is supposed to teach. Pretty cagey, these professors.

At the beginning the people in your class seem like nice enough folks. But gradually everyone begins to realize that their only hope of getting a job is to blast the chromosomes out of their classmates in the giant zero-sum thermonuclear war game called "class standing." Class standing is what saves law school from being a boring, cooperative learning experience and makes it the dynamic,

3. This form of mayhem has, of course, nothing to do with the technique by which Socrates gently sought to have his students teach themselves the truth hidden inside each of them. The only connection that the law school version of the Socratic method has with education is that it teaches you to hate the sound of your own name. Christopher Columbus Langdell of Harvard was one of the first advocates of the Socratic method of law teaching. His teaching style was so unpopular that Harvard's law school enrollment plummeted, and rumors circulated that Langdell might be fired. When law professors across America learned how much students despised the method, however, they immediately rushed to adopt it, and Langdell's job was spared. See R. STEVENS, LAW SCHOOL: LEGAL EDUCATION IN AMERICA FROM THE 1850's TO THE 1980's, at 52, 66 n.15 (1983). 
exciting, survival-of-the-fittest, cutthroat, competitive, grueling treadmill of unsurpassed joy that it is.

Class standing does irreparable psychic injury and scars bright and creative people for the rest of their natural lives. Following law school graduation, it often happens that a bright and creative person is about to do something bright and creative, but then thinks, "No, I was only number 67 out of 150 in my class. I'm probably not capable of any mental activity greater than picking slugs off zucchini plants." So she doesn't do anything.

To make sure that the message gets through, the professors are not content with the demeaning and humiliating exercise of calculating class standing. No. First, they tell students that class standing and grades do not matter. Not at all. They know that the students will remember the episode with the commercial outlines and will therefore conclude that nothing else in the entire universe matters except class standing and grades. Then, to strike the final blow, the professors adopt a grading system straight out of the seventh level of Dante's Inferno. They take students who have undergraduate GPA's of A-minus, and who have never gotten a B-minus in their entire lives, and they give them-get this-all C's!!! This will prove that the professors know the law better than the students, in case that point was somehow overlooked. Most law students never recover from this act of evil genius. They spend the rest of their lives figuring out how to get even with the rest of humanity. ${ }^{4}$ This is also the reason that Supreme Court Justices are always so testy with each other in their opinions. An example: "When two of our esteemed colleagues left the majority and joined the dissent, it raised the average IQ in both groups by thirty points." HA! The Justices are still hopping mad about that C-minus they got in civil procedure forty years ago.

During the first year, the law students quickly divide into three groups:

The Active Participants: Overconfident geeks who compete with each other to take up the most airtime pointing out that before law school, when they were Fulbright Scholars, they thought of a question marginally relevant to today's discussion. Their names appear on the class' "Turkey Bingo" cards, a game you win if five people on your card speak during one class period. The Active Participants stop talking completely when first-semester grades come out and they get all C's.

The Back Benchers: Cool dudes who "opt out" of law school's competitive culture and never prepare for class. They sit on the back row, rather than in their assigned seats, so the professor can't find them on the seating chart. They ask if they can "borrow" your class outline.

4. This all-consuming desire for vengeance is called "appropriate lawyerly zeal." 
The Terrified Middle Group: People who spend most of their time wondering what the hey is going on, and why don't the professors just tell us what the law is and stop playing "hide the ball" and shrouding the law in mystery/philosophy/sociology/nihilisticrelativism/astrology/voodoo/sado-masochistic Socratic kung fu?

The cases are, of course, dreadfully boring. There are, however, a few interesting characters you will meet in the legal literature, like the "fertile octogenarian," the "naked trespasser," and the "officious intermeddler." It is best to keep these three people from spending much unsupervised time together. Also, there are a few interesting cases, such as Cordas v. Peerless Transportation $\mathrm{Co}_{.}{ }^{5}$ in which the judge was apparently a frustrated playwright:

This case presents the ordinary man-that problem child of the law-in a most bizarre setting. As a lowly chauffeur in defendant's employ, he became in a trice the protagonist in a breath-bating drama with a denouement almost tragic. It appears that a man, whose identity it would be indelicate to divulge, was feloniously relieved of his portable goods by two nondescript highwaymen in an alley near 26th Street and Third Avenue, Manhattan; they induced him to relinquish his possessions by a strong argument ad hominem couched in the convincing cant of the criminal and pressed at the point of a most persuasive pistol. Laden with their loot, but not thereby impeded, they took an abrupt departure and he, shuffling off the coil of that discretion which enmeshed him in the alley, quickly gave chase ....6

This judge was obviously having such a good time it's hard to believe that the point of all of this humor was (chuckle, chuckle) to hand down a decision against $a$ woman and her infant children who were injured by a runaway taxi. ${ }^{7}$

Another strange, but interesting, example of our judiciary in action is United States ex rel. Mayo v. Satan and his Staff, in which the plaintiff sued Satan under federal statutes for violating his civil rights. He alleged that the defendant had on numerous occasions caused him misery, plagued him with unwarranted threats, placed deliberate obstacles in his path, and caused his downfall, and therefore had deprived him of his constitutional rights. The court denied the plaintiff's application to proceed in forma pauperis, holding:

We question whether plaintiff may obtain personal jurisdiction over the defendant in this judicial district. The complaint contains no allegation of residence in this district. While the official reports disclose no case where this defendant has appeared as defendant there is an unoffi-

5. 27 N.Y.S.2d 198 (N.Y. City Ct. 1941).

6. Id. at 199.

7. Id. at 200.

8. 54 F.R.D. 282 (W.D. Pa. 1971). 
cial account of a trial in New Hampshire where this defendant filed an action of mortgage foreclosure as plaintiff. The defendant in that action was represented by the preeminent advocate of that day, and raised the defense that the plaintiff was a foreign prince with no standing to sue in an American Court. This defense was overcome by overwhelming evidence to the contrary. Whether or not this would raise an estoppel in the present case we are unable to determine at this time.

We note that the plaintiff has failed to include with his complaint the required form of instructions for the United States Marshal for directions as to service of process. ${ }^{9}$

The plaintiff in Mayo sued without a lawyer, because suing the devil would present lawyers with an obvious conflict of interest.

But most cases are, in Mark Twain's phrase, chloroform in print. ${ }^{10}$ Show me a person who finds them fascinating, and I'll show you a charisma coach for Calvin Coolidge.

\section{THE LAW FACULTY}

The law faculty is a distinguished group of prison guards who sit in attack formation at law school assemblies. If you want to know what kind of people law professors are, ask yourself this question: "What kind of a person would give up a salary of a jillion dollars a year in a big firm to drive a rusted-out Ford Pinto and wear suits made out of old horse blankets?" Think about this carefully before asking your professor's opinion on any subject.

A law professor's greatest aspiration is to be like Professor Kingsfield in the movie The Paper Chase. One professor who saw the movie decided (this is a true story) to act out one of the scenes from the film in his class. He called on a student, who replied that he was unprepared. The professor said, "Mr. Jones, come down here." The student walked all the way down to the front of the class. The professor gave the student a dime, and said, "Take this dime. Call your mother. Tell her that there is very little chance of your ever becoming a lawyer." Ashamed, the student turned and walked slowly toward the door. Suddenly, however, he had a flash of inspiration. He turned around, and in a loud voice, said, "NO, Clyde." (He called the professor by his first name.) "I have a BETTER idea! YOU take this dime, and you go call ALL YOUR FRIENDS!!!" The class broke into pandemonium. The professor broke the student into little bitty pieces.

Politics are often divisive at law schools. In the 1960's, the faculties were conservative and the students were liberal. In the 1980's, the students were conservative and the faculties were liberal-the professors having spent their

9. Id. at 283.

10. M. TWAIN, RoughING IT 132 (1901). 
formative years as members of the Grateful Dead entourage. The 1970's were a difficult transitional period during which, for an awkward moment, faculties and students were able to communicate. They discovered that they did not like each other.

When law professors are not doing important things like writing commercial outlines, they are writing casebooks. Of course, they make you buy their casebooks for their classes. One of the cardinal rules of casebooks is that they must have as many authors as there are soldiers in the Montana National Guard. The more authors the publisher can recruit, of course, the more classes in which the casebook will be adopted.

Just to prove that at heart they are really gentle, fun-loving people, professors will occasionally do something a little bit zany, like wear a costume to class on Halloween. This makes the students laugh and cheer. Before you laugh and cheer, however, you should check your calendar. It is often difficult to tell whether a professor is wearing a costume or not.

\section{LEGAL WRITING}

During your first year, you take a class called "Legal Writing." The sole objective of this class is to make you write like real lawyers as little as possible. Virtually all lawyers write as if they were paid by the word. Some write as if they were born in a parallel universe. For example, here is the legal translation that has been offered for the simple, everyday phrase, "I give you this orange."

Know all men by these presents that I hereby give, grant, bargain, sell, release, convey, transfer, and quitclaim all my right, title, interest, benefit, and use whatever in, of, and concerning this chattel, otherwise known as an orange, or citrus orantium, together with all the appurtenances thereto of skin, pulp, pip, rind, seeds, and juice, to have and to hold the said orange together with its skin, pulp, pip, rind, seeds, and juice for his own use and behoof, to himself and his heirs in fee simple forever, free from all liens, encumbrances, easements, limitations, restraints, or conditions whatsoever, any and all prior deeds, transfers or other documents whatsoever, now or anywhere made to the contrary notwithstanding, with full power to bite, cut, suck, or otherwise eat the said orange or to give away the same, with or without its skin, pulp, pip, rind, seeds, or juice. ${ }^{11}$

This kind of supernatural incantation is designed to perpetuate the perceived mysticism of the law and its official high priests. Legal writing teachers, however, tell you that it is preferable to use concise language and simple, everyday words. As Benjamin Franklin said, "Never use a long word when a

11. Plain Wayne, WIS. B. BulL., Feb. 1975, at 61. 
short one will do." Of course, he was a printer, and he had to set the type by hand. Naturally, he preferred "pay" over "remuneration."

Lawyers like to use "lawyerisms," like "aforementioned," "hereinafter," and "mortgagee." They also invoke ancient Latin phrases, such as "res ipsa loquitur." This means, "The thing speaks for itself." They never explain, however, WHAT the thing says. The phrase literally says, "The thing for itself speaks." Notice that the words are out of order. No wonder Latin is a dead language.

Sometimes people can't understand you when you use big words. When the loan officer asked Archie Bunker if his home was encumbered, he replied, "No, it's stucco and wood." A writer who uses words unknown to his reader might as well bark. ${ }^{12}$

Lawyers do strange things to language. For instance, they add "-ize" to all sorts of words. They don't say "use"; they say "utilize." They also say "actualize," "initialize," and "prioritize." If you ask me, it's enough to make you "externalize" your breakfast. They should try harder to "laypersonize" their language.

Lawyers also write "said" alot. For example, one complaint stated:

[B]eginning at a point on SAID railroad track about a half mile or more north of a point opposite SAD curve in SAID highway, large quantities of highly volatile coal were unnecessarily thrown into the firebox of SAID locomotive and upon the fire contained therein, thereby preventing proper combustion of SAID coal, resulting in great clouds of dense smoke being emitted from the smokestack of SAID locomotive. ... [Defendant] knew SAID smoke would fall upon and cover SAD curve in SAID highway when SAID engine reached a point on SAID railroad tracks opposite SAID curve, unless SAID smoke was checked in the meantime. ${ }^{13}$

The judges who quoted this language, realizing that they had not yet used up their daily quota, then added another sentence containing eight more "saids."14 Said practice is supposedly invoked for precision, but said precision is illusory. Since the author referred to only one locomotive, "said" is unnecessary. If he had referred to two, "said" wouldn't tell you which one. ${ }^{15}$ The real problem is that "the" doesn't sound important enough to lawyers, so they instead write said "saids."

Another sin of legal writing, as we have noted, is verbosity, which is exacerbated by the practice of using pairs of duplicative words, like "cease and desist," "null and void," "free and clear," "suffer and permit," "devise and

12. The Difference Between Writing and Yelping, CAL. LAW., Oct. 1989, at 136 (quoting an editorial in the San Francisco Chronicle (1941)).

13. Button v. Pennsylvania R.R., 115 Ind. App. 210, 213-14, 57 N.E.2d 444, 445 (1944) (en banc) (emphasis added).

14. Id. at 214,57 N.E.2d at 445.

15. See Wydick, Plain English for Lawyers, 66 CALIF. L. REV. 727, 740 (1978). 
bequeath," and "idiot and senator." This practice supposedly stems from periods in history when English lawyers had two languages to choose from: first, Celtic and Anglo-Saxon, then English and Latin, and later English and French. But who really knows for sure whether this is true and correct?

A select group of judges have pursued the virtue of conciseness with a passion. For example, a taxpayer in the U.S. Tax Court testified, "As God is my judge, I do not owe this tax." Judge Murdock replied, "He's not, I am; you do."16 Another example is Denny v. Radar Industries. ${ }^{17}$ The opinion in that case contains very few words beyond the following language: "The appellant has attempted to distinguish the factual situation in this case from that in [a prior case]. He didn't. We couldn't. Affirmed."18

Another common boo-boo in legal writing is the mixed metaphor. This is a figure of speech that begins with one image and then, as slick as Elvis' hair grease, shifts to another. For example, a bar association committee reported that it had "smelled a rat and nipped it in the bud." 19 Donald Nixon complained, "People are using Watergate as a political football to bury my brother." ${ }^{20}$ Even Jiminy Cricket told Pinocchio, "You buttered your bread-now sleep in it."21 Therefore, before wedding a mixed metaphor to the very fabric of your argument, be sure to run it up the flagpole of microscopic scrutiny. Otherwise, the sacred cows will come home to roost with a vengeance. ${ }^{22}$

Lawyers also use a lot of cliches. They say things like, "The case is open and shut. Don't cut off your nose to spite your face." And, "To think that you will escape the day of reckoning in the cold light of reason is the height of absurdity barking up the wrong tree." So bite the bullet and avoid trite cliches like the plague.

Legal writing also often uses double negatives. The U.S. Supreme Court has truly refined this art, writing the world's first and only-believe it or not-quadruple negative: "This is not to say, however, that the prima facie case may not be met by evidence supporting a finding that a lesser degree of segregated schooling in the core city area would not have resulted even if the board had not acted as it did."23

Government cryptographers have been trying to decipher this sentence for years. So far, they have been able to tell that it has something to do with schools.

The second half of your legal writing class is "moot court," a thrilling little death march in which you prepare a hundred-page document that is called,

\footnotetext{
16. As quoted in H. WeIHOFEN, LEGAL WRITNG STYLE 41 (2d ed. 1980).

17. 28 Mich. App. 294, 184 N.W.2d 289 (1971).

18. Id. at 294,184 N.W.2d at 290.

19. See G. BRANDRETH, THE JOY OF LEX 227 (1980) (quoting Boyle Roche).

20. As quoted in G. BLOCK, EFFECTTVE LEGAL WRITING 42 (2d ed. 1983).

21. Pinocchio (Walt Disney 1940).

22. G. BRANDRETH, supra note 19, at 227.

23. Keyes v. School Dist. No. 1, 413 U.S. 189, 211 (1973) (Brennan, J.).
} 
appropriately enough, a "brief." Then you have the privilege of getting in a heated argument with another student in front of a panel of judges composed of extremely experienced second- and third-year students who have never in their lives set foot inside a courtroom.

The worst part of legal writing is having to learn the legal citation system. This is set forth in literally thousands of subrules in a book whose name nobody can remember, but which everybody calls the Bluebook, mostly because it's blue (or, as lawyers put it, "blue in color").

The operating principle of the Bluebook is that "NATURE ABHORRETH A VACUUM," so the Bluebook has provided a way to cite every single source since the invention of papyrus. And, because there's no logic to the system, you have to look up each rule every time. For example, for books you must give the initial of the author's first name, but for law review articles you don't, which I guess is supposed to be some sort of stupid reward for writing books. You are never permitted to give the author's first name for articles, even though there are 4,000 law professors named "Smith." This rule governs unless, of course, the author is a student, in which case you don't give her name at all, which in the past the law reviews also didn't do, but now they do. (Are you following this?) An article by a student is called a "note" or a "comment," but nobody can ever agree on which is which, so people just call it whatever they want. The Bluebook is just chockful of idiot rules like these.

\section{EXAMS}

Studies have shown that the best way to learn is to have frequent exams on small amounts of material and to receive lots of feedback from the teacher. Consequently, law school does none of this. Anyone can learn under ideal conditions; law school is supposed to be an intellectual challenge. Therefore, law professors give only one exam, the FINAL EXAM OF THE LIVING $\mathrm{DEAD}$, and they give absolutely no feedback before then. Actually, they give no feedback after then, either, because they don't return the exams to the students. A few students go and look at their exams after they are graded, but this is a complete waste of time, unless they just want to see again what they wrote and have a combat veteran-type flashback of the whole horrific nightmare. The professors never write any comments on the exams. That might permit you to do better next time, which would upset the class ranking.

Another reason that law professors give only one exam is that, basically, they are lazier than three-toed sloths. They teach half as many hours as other professors, are paid twice as much, and get promoted three times as fast. Then, they whine like three-year-olds because they have to grade one exam per class. I mean, this is every single semester, year in and year out. The constant grind is enough to kill a person, I tell you. 
Since professors won't tell you how to do well on your exams, I will. Because you cover so much material, you need to make an outline for each class. You can do this alone, assuming you have about an extra thousand years to kill. An easier way is for your study group to divide up the classes, with each person outlining one class. This differs from the prior approach in that it is humanly possible. You are likely, however, to open up your study group's contracts outline the night before the exam and find a sentence like this: "An offer is the manifestation of gooberness to enter into a something or other (I didn't catch what the professor said here) so made as to justify another person in understanding that [illegible] is invited and will gyre and gimble in the wabe. Or something like that." You then realize that the classmate who wrote this dropped out six weeks ago and is inaccessible by telephone, and you run around the room screaming like the lunatic that you are. So it's really better just to buy the commercial outline and forget it.

Then, memorize the outline. As you pour it in the top of your head, most of it will run out your ears. Keep scooping up the stuff that runs out your ears and pour it back into the top of your head. Eventually, a little of it will begin to stick. You should also use acronyms, or "pneumatic devices," to help you memorize. For example, the prima facie case of a tort action for negligence has several elements: an Act or omission, a Duty, a Breach, Actual cause, Proximate cause, and Damages. The first letters of these elements are A, D, B, A, $\mathrm{P}$, and $\mathrm{D}$. Now, think of a sentence using words beginning with those letters. For example, Ann Drop-kicked Bunnies And Pretty Duckies. See? You will never forget the elements of negligence again. You can use this technique to remember everything you learn in law school. Using this method, one student was able to reduce his entire civil procedure outline to one word, and finally, to one letter. Then he forgot the letter.

Next, get some of the professor's old exams from the library and try to answer them. As you read them, note that you don't have the foggiest idea what they are asking. You can't even tell what the subject matter of the class was. Put the exams away. This year's test will probably be easier.

Then the two-week exam period begins in earnest, and the typical student begins to feel like a nine-lived cat run over by an eighteen-wheeler. To take their minds off the crush of exams, students engage in a variety of activities, such as:

Trying to concentrate while panicking.

Having anxiety attacks while panicking.

Having diarrhea while panicking.

Panicking while panicking.

I strongly recommend that you type your exams instead of writing them. There are several advantages to typing. For instance, you can bring a "memory 
typewriter," and when the exam begins you can push a button and your typewriter will reproduce your entire outline. This is very handy.

You might find it a little difficult to concentrate in the typing room, because all those typewriters pounding together sound like a herd of elephants doing an impersonation of Gregory Hines. If somebody starts typing before you have even finished reading the first paragraph, don't get upset. It probably means nothing, except that someone is a genius and how are you supposed to compete with a genius and what are you doing in law school anyway!!! Take a deep breath. Take several deep breaths. Now you are hyperventilating and are going to pass out. Cease breathing.

The sound of the typewriters is not the only reason you're having trouble concentrating. You have not slept or eaten for two days. Also, you have not changed your clothes or bathed for a week, and things are beginning to get a little bit itchy. You are wearing a hat to hide the fact that your hair looks like the La Brea tar pits.

Try to hum a tune (to yourself, so that the person next to you doesn't bash you on the head with his typewriter) to help yourself relax. Suddenly - and you have never noticed this before-you realize that "La Bamba" has exactly the same chord progression as "You've Lost That Loving Feeling" and "Twist and Shout." This will probably be hard to do, but let it go for now. You can think about it later-like during your next exam. Twist a little closer to your typewriter, and try to write something quasi-intelligent. Do not shout.

If there is a power failure or your typewriter breaks, don't panic. Calmly remove the paper from the typewriter, gently pick up a pen, and scrawl across the page in ink mixed with blood: "TYPEWRITER BROKE!!!! I WRITE NOW!!!!" Then pass out. To avoid power and equipment failures, you might want to bring in a wheeled cart with about seventeen extra typewriters and a twelve-volt car battery. Better yet, drive a pickup truck full of typewriters into the exam room and open the hood for access to the battery. It would be thoughtful to place a drip pan under the transmission. Also, be sure that the carriage on your typewriter is working, so that you don't end up typing 2,000 letters in one very black spot. This can make your answer hard to read.

The exam questions are usually absolutely hilarious fact situations that just slay students and send them into paroxysms of helpless laughter. Law professors learn how to write these witty exams at a seminar for new professors, "How to Make Up for Your Humorless Teaching Style on the Final Exam." Try not to let the laughing get out of hand.

If your professor has stressed theory all semester and has insisted that there are no legal rules and that only an idiot would believe that there are rules, her exam will test you on the rules and the rules alone. These rules are printed in heavy black typeface in the commercial outlines, and are therefore called "black letter law." Do not confuse them with black letter theory, which will do you no good whatsoever on the exam. 
You should use the "IRAC" method on the exam. "IRAC" stands for Issue, Rule, Application, and Conclusion. Be sure to discuss each part of the formula, except that you can skip the Conclusion, because it doesn't matter which way you come out. Also, there is no time to do the Application, because the exam is so chockful of issues that you barely have time to list them and try to state some semblance of a rule using only key words. It shouldn't really be called the "IRAC" method, but "IR" looks kind of stupid and makes it sound like law school exams test only memorization skills. Which, of course, is what they do.

Be sure to confront any ambiguities in the exam. They probably wound up in there accidently, but the professor will never admit this and will insist that they were deliberately placed there for pedagogical purposes (a phrase you will hear a lot). For example, suppose Don throws acid at Pat. (Notice that "Don" begins with a "D," as does the word "Defendant," and that "Pat" begins with "P," as does the word "Plaintiff." These professors are geniuses.) The exam doesn't tell you whether the acid made contact-i.e., a harmful or offensive "touching" (what a moronic word)-with Pat. You should confront this ambiguity and write the following:

The facts don't say whether the acid touched Pat. If it did not, it was an assault. If it did, it was a battery. Of course, it was clearly a battery if it was-battery acid!!!

Professors just love humorous asides like this, and will probably give you several points of extra credit. ${ }^{24}$

After the exam, do not review—or "post-mortem"- the exam with other students. This is very depressing-especially if you can't even agree whether it was a torts exam or a contracts exam. On the other hand, if some persistent bozo absolutely insists on reviewing the exam with you, be sure to point out several issues that were not on the exam. This will cost him several days' sleep and, probably, thirty pounds.

\section{The SeCond AND ThIRd Years}

The second- and third-years are about the same as the first year, except that you are a cool second or third year student, and you get to choose your teachers (this is called forum shopping) based on the difficulty of their grading curve. The professors believe that you choose their class based on their teaching ability and the centrality of their course to your future career, so it's wisest not to reveal this little secret. The professors describe their courses in a list called, appropriately enough, "Course Descriptions." They try to make the courses sound like interesting and important educational opportunities that no person

24. Or flunk you immediately. Either way, don't blame me. I can't help it if your professor is a prune. 
who calls herself a lawyer would dare overlook. They do this because if no one attends their class, the dean might fire them. Or worse, make them teach Property.

An honest list of course descriptions might look something like this:

Alternative Dispute Resolution (ADR). How people resolve disputes without lawyers, because a simple dogbite case takes five years and $\$ 50,000$ to get to trial. Learn how to recognize ADR and squash it.

Banking Law. Discover why banks throw billions of dollars away, but keep those 98-cent pens chained to their desks.

Civil Procedure. Learn about the paper wars of litigation. Discover why, every time a case is filed, another forest dies.

Commercial Law. How to perfect a security interest in guano at a fertilizer factory.

Conflict of Laws. Memorize thirteen different ways of saying, "If you play in my yard, you play by my rules."

Constitutional Law. Ridicule people who still believe that the Framers' intent has any relevance whatsoever.

Contracts. Study rules based on a model of two-fisted negotiators with equal bargaining power who dicker freely, voluntarily agree on all terms, and reduce their understanding to a writing intended to embody their full agreement. Learn that the last contract fitting this model was signed in 1879.

Corporations. How to abuse creditors, shareholders, employees, consumers, the IRS, and the environment for fun and profit. Mostly profit.

Criminal Law. Study common law crimes that haven't been the law anywhere for more than 100 years. Then, to bring things up to date, study the Model Penal Code, which is not the law anywhere today.

Criminal Procedure. Learn enough about the rationale behind the exclusionary rule to defend yourself at cocktail parties.

Environmental Law. Discover why, if you put an empty oil can to your ear, you can hear the ocean roar. 
Evidence. Memorize the hearsay rule and its 50,000 exceptions. Good for people with a photographic memory and gangs of free time.

Federal Courts. How to administer prisons, schools, and most of society from the bench.

Income Taxation. Prepare to be a tax lawyer. A tax lawyer is a person who is good with numbers but who does not have enough personality to be an accountant.

Jurisprudence. How to be a jurisprude.

Landlord-Tenant Law. See how medieval English feudal law has a modern application.

Lawyering Skills. Spend your hard-earned tuition money to learn what your first employer will pay to teach you anyway.

Legal Ethics. Learn why "honest lawyer" is an oxymoron.

Products Liability. Set yourself up for life by finding a cockroach in your Jolt Cola.

RICO. Learn how to use this powerful anti-extortion law to extort large settlements out of honest business people.

Roman Law. In case you need to sue a Roman.

Securities Regulation. See why humans are the only animals that can be skinned more than once.

State and Local Government. Learn how the broadest governmental powers in America have been reserved to a city council composed of two real estate developers, a retired earthworm inspector, and a proctologist.

Torts. Study a compensation system in which the transaction costs generally exceed the payments to the injured parties. Fortunately, most of the transaction costs occur in the form of attorney's fees.

Wills and Estates. Dead people and their things. Also known as "Stiffs and their Gifts." 
Also, if it hasn't happened already, during your second or third year you will be exposed to two relatively new schools of thought. Although these schools of thought are a little unusual, they are not to be rejected out of hand. They are to be carefully considered and weighed. And then rejected.

One of them is called Critical Legal Studies (CLS). Critical Legal Studies rests on the following irrefutable syllogism:

Major Premise: Lots of cases could be decided either way.

Minor Premise: I don't like the way a lot of cases have been decided.

Conclusion: The law is a crock.

Practical Application: Come the revolution.

When you ask what happens after the revolution, it gets really fuzzy. The "Crits" talk a lot about abolishing "hegemony," "illegitimate hierarchies," and other multisyllabic evils. Some of them argue that, to eliminate illegitimate hierarchies, all jobs should be rotated. (I am not making this up.) So try this. Ask your CLS professor how come he hasn't, even once, let the building custodian teach his class while the professor scrubs out the toilets in the third floor bathroom. Huh? How come? He'll tell you to get the hey out of his office, and to take your hegemonic positivist thinking with you. Suddenly, it dawns on you that in the Crits' post-revolutionary world, some people will be wielding the levers of power and others will be wielding the scrub brushes. Apparently, there are illegitimate hierarchies and legitimate ones. If you know what I mean.

Crits talk funny. One famous CLS article ${ }^{25}$ sounds like "a pair of old acid-heads chewing over a passage in Sartre." ${ }^{.26}$ An example:

It is not inconsistent to, on the one hand, realize the projective temporal character of human existence, in which no one is identity, and the living subject is continually not what he or she is by moving into the next moment in a creative and constitutive way. ${ }^{27}$

Crits also talk about "intersubjective zap" 28 and "unalienated relatedness." 29 They speak in this manner because if they just openly announced that, what the hey, we should overthrow American democracy and replace it with a Marxist ${ }^{30}$ utopia, people would start wondering why the only Marxists left in

25. Gabel \& Kennedy, Roll Over Beethoven, 36 STAN. L. REV. 1 (1984).

26. Luban, Legal Modernism, 84 MiCH. L. REv. 1656, 1671 (1986).

27. Gabel \& Kennedy, supra note 25, at 19.

28. See, e.g., id. at 4.

29. See, e.g., id. at 1 . Crits argue that all power structures, including language, are propped up from the inside, perpetuate hierarchy, and exclude others. Therefore, Crits use an untranslatable, circular, selfreferential vocabulary that supports their arguments from the inside, perpetuates the hierarchy of the Crits as Gnostics who pretend to know a Mystery, and excludes others. See Card, Prophets and Assimilationists, SUNSTONE, Feb. 1989, at 39.

30. Since Crits are radical nondeterminists, they quite naturally advocate one of the most deterministic political ideologies ever created: Marxism. 
the entire world teach at American universities. The Crits' strategy has worked pretty well, considering that they have been able to last nearly two decades on about ten minutes' worth of ideas.

The other school of thought is called "Law and Economics." While Crits believe that all law is aimed at SUPPORTING free market capitalism, the "Econs" believe that all law is an unwarranted INTERFERENCE with free market capitalism. Other than that, the two groups pretty much see eye to eye. ${ }^{31}$

Econs basically believe that material wealth is the highest human value, and that justice, fairness, dignity, and protecting the helpless all cost money and are therefore "economically inefficient." The money would be better spent on much more transcendent things, like pet rocks, hemorrhoid pads, and other items needed to satisfy AGGREGATE DEMAND.

Econs prove their theories by devising little mathematical formulas which assume whole truckloads of untrue things and then come to a particular conclusion. The conclusion is always-get this-" "the market will take care of it itself." According to the Econs-I am not making this up, either-there is a GIANT INVISIBLE DISEMBODIED HAND that magically takes care of everything. Before you get too excited about this, remember that this is the same invisible hand that gave us the invisible GREAT DEPRESSION. Oh. That invisible hand.

When you point out that the assumptions in the formulas are simplistic (a euphemism for "false"), the Econs get really testy and tell you that you don't understand the discipline. ${ }^{32}$ Besides, although sitting in an office and writing little mathematical formulas may not be the most effective way to solve the world's problems, it is at least one of the highest paid, and you can't have everything. Moreover, Law and Economics doesn't require any empirical studies, which, after all, would be tedious and time consuming. So the Econs don't want to hear you say that their beautiful theories are about to be murdered by a brutal gang of facts. Also, they have no time to listen to you, as they are too busy trying to get the math section back on the LSAT.

Let me give you an example of Law and Economics. Suppose Seller has signed a contract to sell widgets to Buyer. Then Third Party comes and offers Seller one dollar more than the contract price. Many Econs believe-now listen closely-that Seller has a MORAL OBLIGATION to breach his solemn contract with Buyer and pay damages so that the widgets will go to their highest and best use. Econs call this greedy and wretched act of treachery an

31. Compare the debate between liberals and conservatives. Liberals want to regulate business activity but not sexual conduct, while conservatives want precisely the opposite. In short, each group wants to regulate the other.

32. "Economics is a closed system; internally it is perfectly logical, operating according to a consistent set of principles. Unfortunately, the same could be said of psychosis." J. JONES \& W. WILSON, AN INCOMPLETE EDUCATION 124 (1987). 
EFFICIENT BREACH. Never mind that Buyer has to scramble to find other widgets. Never mind that BUYER should have the opportunity to sell the widgets to Third Party and get the profits, instead of that breaching grimeball Seller. Never mind that the certainty and stability of contracts will be undermined, resulting in fewer contracts and ultimately less economic exchange. Although Econs admit that this free-for-all law-of-the-jungle auction-without-a-gavel may be unjust, justice is mere chickenspit compared to wealth. While money may not buy happiness, it at least affords us the particular kind of misery that we most enjoy.

So the Crits attack from the left and the Econs from the right. The Crits are negative and the Econs are positive. Wouldn't it be fun to put all the Crits and Econs in the same room and see whether, like ions, they combine to form one humongous molecule of inert gas? Unfortunately, since most of these people refuse to get in the same room with each other, modern science will never know whether it would work. I bet it would, though.

\section{COCURRICULAR PRograms AND StUdent ORganizations}

Being fully committed to providing the best possible educational opportunities for every student, law schools offer cocurricular programs, like law journals and moot court. Then, quite naturally, they let hardly anyone participate in them.

The most elitist organization is the law review, which is generally restricted to the top ten percent of the class. These students are given this special honor so that employers will not overlook them just because they are at the top of their class. Law review editors spend their time doing meaningful educational tasks like checking the citation form of articles they don't understand. They are the big snots around the school.

Many law schools have also started other law journals. These journals usually focus on a specific area of the law, and have names like The Journal of Comparative Funeral Law, or The Review of International Agreements Governing Intestinal Tapeworms (Northern Hemisphere). They concentrate in a particular area so that they don't have to be named The Second-String Law Review, which they would consider somewhat demeaning.

The second type of cocurricular program is upper-level moot court. These students are the ones with bared fangs and fire in their eyes, who can't wait to get out of school and litigate the living corpuscles out of every warmblooded creature. So they start doing it in law school. They also get to go to competitions in distant places, like Eyesocket, Nevada. Compared to attending law school classes, this is pretty exciting.

There are also student organizations. Some of these ostensibly focus on a particular topic or interest, like "The Coalition for the Legal Empowerment of Undersea Protozoa," or "Future Trial Attorneys for the Clinically Brain Dead." 
However, they really exist only to provide resume padding. A student wants to be able to say that he is the Exalted Grand Excellent Potentate of the Ancient Royal Order of Back Benchers. This is supposed to impress employers.

Other student organizations, like legal fraternities, don't make any such pretense. They openly admit that they exist to advance people's careers. They put up posters showing that five of the presently sitting Supreme Court Justices (a working majority) belong to Beta Grabba Fee. The posters also include testimonials from lawyers basically saying that it's who you know that counts, and that if they had not belonged to that particular fraternity, their careers would have been in the toilet. So give us your sixty bucks. These organizations perceive no need to have an independent reason for existing, since fear and greed can legitimately stand on their own.

Another organization, the Federalist Society, has appeared at some American law schools and is attempting to return us to that golden age when states were as yet unencumbered by the Bill of Rights. Their organizational efforts have been impeded, however, by the fact that Federalist membership dues must be paid in gold coins, since the Society refuses to recognize paper money as legal tender.

\section{INTERVIEWING FOR JOBS}

It used to be that, at the beginning of their second year, students would participate in on-campus interviews for employment nearly two years later. Employers quickly recognized, however, that this was not nearly early enough. So, job interviews now begin in the fall semester of the students' first year, nearly three years before they graduate. The students work for the law firms the following summer and have a dandy time being escorted around to fancy restaurants and on trips down the Colorado River. Of course, much as the students appreciate these flattering jaunts, they cannot help but notice that they never meet any lawyer who actually works for the firm in any of these places (other than those who are actually engaged in chaperoning the law students).

Before you interview, you will need to prepare a "resume." It is also called a "curriculum vitae," a Latin phrase meaning "preposterous fable." There is a fine art to interpreting resumes. "Top 10\%" means "top 20\%." "Top 20\%" means "top half." "Middle of the class" means "bottom half." Law schools get extremely angry when students pad their resumes like this. They give moralistic lectures telling students that it is just plain dishonest. Because they are the nation's leading law schools, the twenty-five schools in the Top Ten get particularly huffy about it. One final suggestion: to avoid unwarranted federal interference, take care not to send your resume through the mails.

People realize that it is impossible in one twenty-minute interview to learn enough about a firm to decide whether you want to trust to its care your career training, your professional reputation, the financial security of you and your 
family, and all your waking hours for the rest of your entire life. Doing that takes at least two or three twenty-minute interviews. For this reason, law firms invite you to make a "call-back," a "fly-out," or a "dogsled-ride-back," depending on where they are located. Whatever they call it, you get to spend a day at the firm and learn all there is to know. Pay special attention if you are walking down the hall and an associate cracks open a door and whispers to you, "Pssst. Get out of here while you still can!" This is generally not a good sign.

You should ask how many hours associates are required to bill. In some firms, associates bill as many as 3,000 hours a year. Sometimes this is accomplished through "triple billing," a technique by which an associate works on client $A$ 's matter while flying to a city for client $B$, and he thinks that the issue may possibly somehow someday be relevant to client $C$. So he bills each client full bore. It is also accomplished through a time warp on the 14th floor, which allows associates to bill fifteen hours in a ten-hour day.

In any case, associates work very hard. One student asked if the associates ever do anything fun together. "Sure," the interviewer replied. "About two o'clock, we knock off for an hour and go play a game of racquetball." The student observed, "What a great way to break up the afternoon." The interviewer responded, "Afternoon?"

Lawyers are defined as "professional employees" and are therefore exempt from the federal labor laws, which set forth the minimum standards of human decency. If during your visit to the restroom you see cots and complete changes of clothing, this is a bad sign. It is an especially bad sign if the law firm is having its offices rezoned as "residential."

Let me explain how large law firms work. The partners hire associates, pay them about a third of the income the associates bring in, and keep the rest. Naturally, the more associates and the fewer partners, the better. After the associates have billed a gazillion hours a year writing memos for seven years, the partners throw them out on their ears and hire new associates. ${ }^{33}$ Large law firms therefore combine the best features of an indentured servitude, a sweatshop in the garment district, and a pyramid scheme.

If you make partner, life is not much better. The definition of a partner is a "self-employed slave." Partners spend most of their lives squabbling like a pack of hyenas over the firm's profits. This is what it means to practice at the highest level of a noble profession dedicated to the ideal of public service, to be the defenders of liberty and the architects of social worlds. It is also what it means to be a hyena. So all in all, the big firm scene might not be for you. Particularly if they don't make you an offer.

33. During the recent economic downturn, however, law firms found that normal attrition was inadequate, and partners could be seen throwing associates out of windows like sandbags. 
You should not get discouraged, however. You should remember that there are many job opportunities and lots of different types of work that lawyers do. For example:

Corporate Work: drafting documents for scumsucking corporations that poison huge numbers of innocent people.

Litigation: defending scumsucking corporations that poison huge numbers of innocent people.

Criminal Defense: defending scumsucking individuals who poison a few innocent people at a time, mostly because they lack the capital and technology to poison huge numbers of innocent people.

Public Interest Work: suing scumsucking corporations that poison huge numbers of innocent people. Lawyers doing this work earn less than what the law firms on the other side of the litigation pay their pencil sharpeners.

Weigh your options carefully.

If you want to delay making a choice, or if you want to wean yourself from poverty slowly, you might do a judicial clerkship for a year. This is an opportunity to hone your skills polishing the shoes and ironing the robes of some political hack with life tenure. You might get to clerk for an "Associate Justice" of the U.S. Supreme Court, or maybe even a "Full" Justice. If so, you get to write constitutional decisions that dramatically change the entire structure of Western Civilization (drawing broadly on your vast experience as a law student and your undergraduate degree in Sports Medicine), while your Justice whiles away the time sharpening the teeth of his prize pit bull with a chainsaw, or whittling the heads off dolls. Also, you get to write repeatedly the two words most commonly used by Supreme Court Justices: "Habeas denied."

\section{MAKING YOUR GETAWAY}

Before you graduate, when you have almost completed law school, you take a test called the "Professional Responsibility Exam." This test asks you questions about ethics and morality. If your answers reveal that you have the slightest trace of a conscience remaining, you are scheduled for surgery. During the surgery they remove the particular lobe of the brain that is causing the problem. This procedure may seem harsh, but without it you would be completely incapable of functioning as a normal lawyer. Perhaps you have noticed that many young lawyers wear sporty sweatbands on their heads when they play racquetball. They do this to hide the scar. 
After you have graduated, you have to go through an initiation rite similar to those of certain college fraternities and sororities. Initiates to those groups get off easy, however, since they only have to eat live chickens and stuff goldfish up their noses, whereas you have to go through eight weeks of projectile vomiting called "Preparing for and Taking the Bar Exam." The state bar association says that bar exams are designed to ensure the competency of the practicing bar. You learned about them in your antitrust class, under the topic of "Market Entry Barriers." They make it possible for people who are already admitted to the bar to make a living wage (i.e., about $\$ 200,000$ a year). You will probably feel somewhat better about the exam's rationale after you pass it.

You will need to take an intensive, eight-week course, costing a drillion dollars, to prepare for the bar exam. Wait a minute, you say. Why did I borrow ten drillion dollars (exceeding the national debt of some third-world countries) and spend three years of my life going to law school? Didn't law school teach me the law? No, you idiot. Law school's purpose is not to teach you the law. Law school taught you to THINK LIKE A LAWYER, unless you attended one of the elite schools, and then it taught you to think like a medieval philosopher, or a business school dropout. So you have to take the bar preparation course.

Before you take the bar and become a "full-fledged" 34 lawyer, you must do one more thing. You need to ask your law school dean to write a letter recommending you for admission to the bar. The dean's time is very limited, since he teaches a full three hours out of a forty-hour week. Your dean will probably send a recommendation letter that looks like this:

34. As in "vulture." The principal difference between a lawyer and a vulture is that the vulture doesn't take off its wingtips at night. 
Dear Sir or Madam:

I have been asked to write a letter recommending for admission to the state bar. Since I write a lot of these letters, I trust you will not object to the format below. I have checked the appropriate blanks. In my judgment, this person:

Integrity

Is as pure as the driven snow.

Is as pure as the driven snow after it has lain on the ground for a couple of days and gotten yucky stuff all over it.

slithered out of a Dickens novel.

Intelligence

Is as brilliant as Einstein, but has a better hairdresser.

Meets the implied warranty of merchantability: is fit for the ordinary purposes for which lawyers are used.

Received an F-minus in my class. Giving this person an F would have been unfair to the people who failed normally.

Knowledge

Understands the Rule Against Perpetuities, and has explained it to me several times.

Knows what "unalienated relatedness" means.

Realizes now that no other success can compensate for being a total failure.

Aspirations

Desires world peace, equal justice, and an end to hunger and poverty. Also wants a red Porsche with mink upholstery.

Therefore, I do do not recommend this person for admission to the state bar.

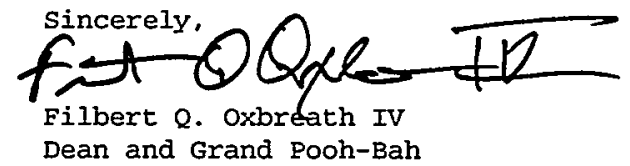

Since your dean took the time from his crushing schedule to write this letter for you, he must not be such a bad person after all. In fact, from now on he will make you one of his personal pen pals. Even though he didn't have two seconds for you in law school, you will suddenly become his close, first-namebasis, bosom buddy forever. Throughout your entire mortal existence, no matter where your career takes you, through all the ups and downs of life, your dean will regularly write you thoughtful and personally computer-generated letters-asking you for money. You just can't put a price on a friendship like that. $\mathrm{He}$, however, does have a ballpark figure in mind. 
So now you know all there is to know about law school. If you haven't yet decided whether to go to law school, you should consider it carefully. If you are in law school now, you should also consider your options. But if you want my objective, even-handed, carefully considered advice, I'll tell you:

GET THE HEY OUT OF IT WHILE YOU STILL CAN!!! 